\title{
Plant and Biomass Extraction and Valorisation under Hydrodynamic Cavitation
}

\author{
Zhilin Wu ${ }^{1}$, Daniele F. Ferreira ${ }^{1,2}$, Daniele Crudo ${ }^{3}$, Valentina Bosco ${ }^{3}$, Livio Stevanato ${ }^{1}$, \\ Annalisa Costale ${ }^{1}$ and Giancarlo Cravotto ${ }^{1, *}$ (B) \\ 1 Dipartimento di Scienza e Tecnologia del Farmaco, University of Turin, Via P. Giuria 9, 10125 Turin, Italy; \\ zhilin.wu@unito.it (Z.W.); danielef.f@hotmail.com (D.F.F.); livio.stevanato@unito.it (L.S.); \\ annalisa.costale@unito.it (A.C.) \\ 2 Departamento de Tecnologia e Ciência dos Alimentos, Universidade Federal de Santa Maria, \\ CEP 97105-900 Santa Maria, Brazil \\ 3 E-PIC S.r.l., Via XXIV Maggio 20, 13888 Mongrando, Italy; daniele.crudo@epic-srl.com (D.C.); \\ valentina.bosco@epic-srl.com (V.B.) \\ * Correspondence: giancarlo.cravotto@unito.it; Tel.: +39-011-670-7183
}

Received: 15 November 2019; Accepted: 12 December 2019; Published: 17 December 2019

\begin{abstract}
Hydrodynamic cavitation (HC) is a green technology that has been successfully used to intensify a number of process. The cavitation phenomenon is responsible for many effects, including improvements in mass transfer rates and effective cell-wall rupture, leading to matrix disintegration. $\mathrm{HC}$ is a promising strategy for extraction processes and provides the fast and efficient recovery of valuable compounds from plants and biomass with high quality. It is a simple method with high energy efficiency that shows great potential for large-scale operations. This review presents a general discussion of the mechanisms of $\mathrm{HC}$, its advantages, different reactor configurations, its applications in the extraction of bioactive compounds from plants, lipids from algal biomass and delignification of lignocellulosic biomass, and a case study in which the HC extraction of basil leftovers is compared with that of other extraction methods.
\end{abstract}

Keywords: hydrodynamic cavitation; process intensification; rotor/stator hydrodynamic rector; plant extraction; biomass treatment

\section{Introduction}

The sustainable valorisation of bioresources for the production of value-added products and biofuels [1-3], has become a hot topic over the past 20 years looking for a carbon footprint reduction. Extraction from biomass is often found as a pre-treatment for the production of bioenergy and platform chemicals, while the extraction of bioactive compounds is directly exploited by pharmaceutical, cosmetic, agrochemical and food industries. Even the valorisation of hard food-waste, such as cocoa shells, can be achieved via the efficient extraction of high value-added components with green protocols [4]. However, the complexity of extraction methods, the flexibility of bioactive components, and request of hazardous solvents and chemicals are still barriers to the widespread use of natural products [5]. As consumer demand grows, greener techniques have become extraction alternatives, especially for the nutraceutical, pharmaceutical and cosmetic manufacturing industries [6].

Microalgae and other microorganisms have become some of the most promising feedstocks for biodiesel production $[7,8]$. Some of the advantages that the development of biodiesel production from microalgae include high productivity, improved food security and a contribution to solving the problem of global warming.

For the efficient extraction of intracellular metabolites proteins, carbohydrates and lipids, the cell disruption is a crucial procedure [9]. However, the toughness of microalgae cell walls and membranes 
results troublesome when extracting most microalgae species. Hence, cell disruption is an energy intensive process [10] that causes a distinct problem: high-cost lipid extraction for the production of low-value biofuels $[9,11]$. Efficient microorganism surface disruption can be achieved by mechanical methods, including ultrasound, shock wave, high-pressure homogenisation, shear stress, bead milling and micro-fluidiser techniques [12]. High-pressure homogenisers and sonication entail specific energy consumption in the order of hundreds of MJ per kg dry mass; obviously, it is inappropriate for the production of biofuel (mega litres/day) [9]. By contrast, energy consumption is significantly reduced in hydrodynamic cavitation (HC) processes, which potentially fit the lipid extractions at large-scale $[8,10]$.

As a highly renewable natural resource, lignocellulosic biomass (LCB) is the most economical in the world [13]. It is an abundant feedstock to produce biofuels and platform chemicals in future [14]. In the context of sustainability, LCB mainly refers to agricultural and forest residues, such as rice and wheat straw, grasses, corn stover, bagasse and wood residues, as their use does not deplete sources of food and animal feed [15]. LCB is generally involves 30\% to $50 \%$ cellulose, $20 \%$ to $40 \%$ hemicellulose and $10 \%$ to $30 \%$ lignin, depending on material type [14]. However, cellulose and hemicellulose are densely packed in layers of lignin, which hinders the enzymatic digestibility of the cellulose present in LCB [16]. In order to facilitate the enzymatic hydrolysis of cellulose, pre-treatment is required to destroy the lignin layers, expose the cellulose and hemicellulose, and therefore increase the yields of sugars from the fermentation of cellulose and hemicellulose [15-17].

Recently, the pre-treatment of biomass, including mechanical, chemical, biological and combined methods, has been extensively studied. Above $90 \%$ of the theoretical sugar yield from biomass has been achieved via a number of methods [17]. Extraction techniques, such as maceration, reflux and Soxhlet extraction, are common processes in the purification and recovery of components from plant materials. However, some processes involve extreme temperatures and pressures [18]. Conventional extractions are laborious and time-consuming. In addition, the large amounts of organic solvents consumed cause healthy and environmental issues. They also cause the degradation of thermally sensitive components and excessive disposal costs [19]. Therefore, pre-treatment conditions must be adapted to the specific chemical and structural composition of the biomass [16]. Major technological innovations that are based on more economical and environmentally friendly methodologies are therefore currently in development in both academic laboratories and industry [18].

One novel approach, HC-based extraction (HCE), is gradually seeing more use in the extraction of bioactive compounds and antioxidants from plants [4,5,20], lipids from algal biomass [7,10,21,22] and delignification of LCB [23-26]. HCE generates in a flowing liquid shock waves, microjets, shear forces, turbulences, etc. during extreme implosion of cavitation bubbles, which is caused by a drop and successive rise in local pressure [27]. In this context, both the production of low-value bioenergy (biogas, bioethanol and biodiesel) and added-value chemicals (antioxidants and follow-up products based on lignin and cellulose) can be accomplished thanks to efficient delignification and the extraction of intracellular components using HCE. The latter is a new strategy and an alternative method that can provide highly efficient, convenient and low-cost extractions. The design of HC reactors (HCRs) and parameter studies offer much knowledge that aids in the development of innovative, eco-friendly and efficient processes.

\section{Advantages of HC Extraction}

Ultrasonic processing is a consolidated technique in solid-liquid extraction from laboratory scale to industrial applications. Generally, ultrasonic systems are less energy efficient than HC units [28]. The most important limitation of ultrasound is poor pressure-wave penetration through solid-liquid mixtures, meaning that cavitation effects only occur near the vibrating surface, leaving most of the mixture untreated.

Although HC is a harmful event for hydraulic equipment, it offers significant promise to intensify a variety of physical and chemical processes [29-31], as fluid energy can be used as an alternate energy source. HC technologies emerged in the 1990s and have been used in the fields of the environmental 
remediation, food processing, and biofuel production with the advantages of process acceleration and higher energy efficiency $[29,30,32]$.

In order to efficiently extract valuable products and precious components from the agriculture and forest residues, as an enabling technology HCE has been employed to achieve better extraction yields, and produce healthy and high-quality products. Moreover, it demonstrates the capacity to potentially eliminate the need for toxic solvents, as well as reducing capital costs, resource consumption and production time $[5,6,27]$. In particular, HCE can be carried out on much larger operation scales with better energy efficiencies, and can also boast of its simple configuration and system construction compared to acoustic cavitation-based processes [29-31].

\section{HC Reactors: Technical Aspects}

Cavitation is termed as the creation of microbubbles, successive expansion and contraction, and then collapse in a liquid [33,34]. HC phenomena are usually generated in a fluidic region in which the pressure drops under the vapour pressure when a liquid stream or liquid/solid mixture passes through a fluidic control device. These microbubbles then collapse in higher pressure regions and lead to powerful shear forces, extreme pressures and temperatures in localised regions. The intense implosions facilitate some cavitation sub-effects, including turbulence, shock waves, microjets, free-radical generation, etc. [34,35].

Although HC phenomena are still regarded as inevitable trouble in flow systems, the deep interest that has been shown in the use of $\mathrm{HC}$ as a tool for the intensification of various physical/chemical processes led to the development of various devices, both static and dynamic [31]. In particular, the high-energy microenvironments (mainly mechanical effects) created by cavitation significantly enhance the deconstruction of biomass with lower energy requirement [4]. Likewise, HC can enhance extraction efficiency thanks to an improved mass transfer rate and cell-wall rupture [6]. This improved mass transfer has been proven in the formation of nanoemulsions using $\mathrm{HC}$, which is also an efficient means for the transport of insoluble bioactive compounds [36].

Orifice plates [22,24,35,37-39], Venturi tubes [40,41], and high-pressure nozzles [42-48] are examples of static HC elements [49]. While they are cheap and simple devices, but they require powerful feeding pumps due to the high pressure loss needed to generate $\mathrm{HC}$ in these types of devices. Moreover, they run into frequent clogging problems, resulting in profit loss, when treating solid-liquid mixtures. Rotary equipment and dynamic cavitational elements were developed with the aim of overcoming these problems and generating HC with less energy input $[25,43,44,50-57]$. An example of this can be found in the rotor-stator device (RSD), which was developed by the University of Ljubljana. It is a cavitator that is made up of a set of teeth that are radially spaced both on the rotor and stator [58]. This device has been used to successfully treat suspensions, such as in sludge treatment for extra biogas production [59]. This paper Illustrates the mechanisms via an analysis of HCRs structure and a comparison of their ability to break up nanoparticle clusters, disrupt the cells of microorganisms and emulsify immiscible mixtures, so that the efficiencies and advantages of various HCRs on the plant and biomass extraction and valorisation can be well demonstrated.

\subsection{Orifice-Structure HCRs}

\subsubsection{Orifice Plates}

The loop orifice plate-type HCR (OP-HCR) is a common HC device for water disinfection and wastewater treatment (Figure 1) [35,60]. In general, hole diameters are in the 1-6 mm range depending on hole number and tube diameters, while orifice plate inlet pressures $\left(P_{1}\right)$ are less than $1 \mathrm{MPa}$. Negative downstream pressures $\left(P_{2}\right)$ can also cause cavitation when a pump is installed downstream of the orifice plate [61-64]. 

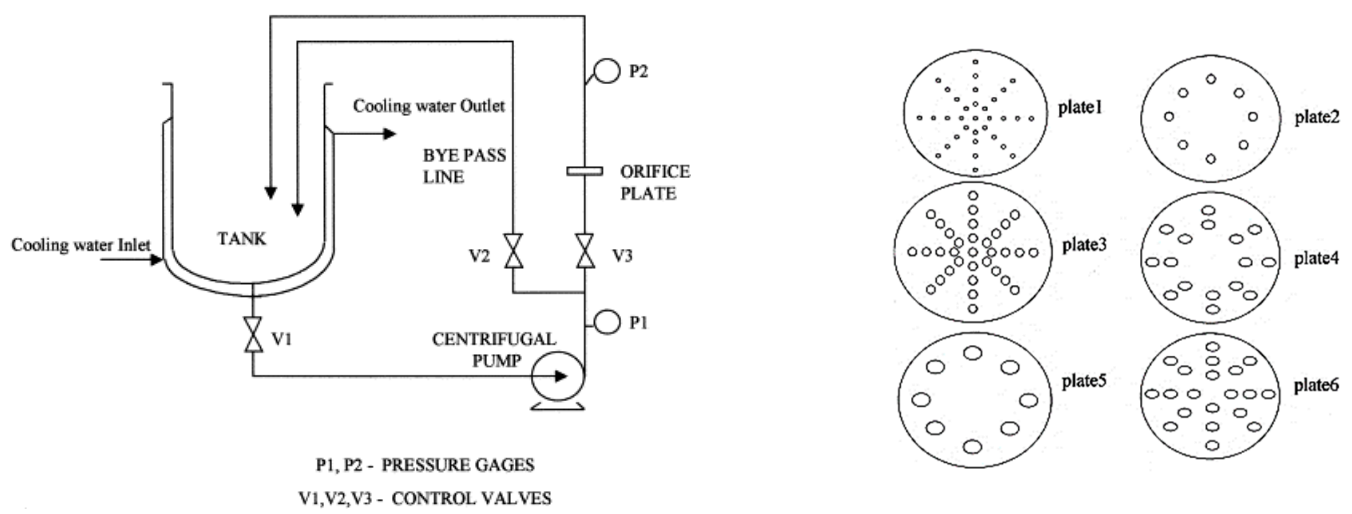

Figure 1. Schematic of HC device equipped with various orifice plates. (Reproduced with permission from Gogate [60]).

The cavitation number $\left(C_{v}\right)$ is usually employed to characterise the cavitation event [65]:

$$
C_{v}=\frac{P_{2}-P_{v}}{0.5 \rho v^{2}}
$$

where $P_{2}, P_{v}, v, \rho$ present the downstream pressure of the OP, the vapour pressure of the liquid at the operating temperature, the velocity of the liquid at the OP and the liquid density, respectively. Under ideal conditions, cavitation occurs at $C_{v}<1.0$.

Based on theoretical calculations, the energy efficiency of using HC is nearly an order of magnitude higher than that using ultrasound for the inactivation of microorganism [33]. The hole size, number and layout of orifice plates, the cavitation number, and the processing time all significantly influence the cavitational efficiency [37]. In general, cavitation effects increase with decreases in hole size and increases in hole number, processing time and flow velocity at the orifice plate. Reynolds shear stress augments with reduction in cavitation number, thus enhancing the cavitation efficiency [37]. Beside shock waves, the turbulent shear generated by the stable oscillation of cavities significantly contributes to the disruption of cells [39]. Therefore, the cavitation efficiency is closely linked to the shear stress, turbulence and pressure pulse formed from cavitation collapse, as well as the mechanical resistance of microbial cells [33].

In addition, the algal species have different responds to the extreme cavitation effects. Microcystis aeruginosa (gas-vacuolate) is more easily disrupted than gas-vacuole-negative alga Chlorella sp. [66]. As an indicator of lipid peroxidation, the increase of relative malondialdehyde content significantly proved the formation of free radicals during HC treatment. Moreover, the free-radical yield increased with the addition of $\mathrm{H}_{2} \mathrm{O}_{2}$, which improved algal reduction in the OP-HCR. Higher algal removal $(88 \%)$, compared to $39 \%$ algal removal using an ultrasonic process, and energy efficiency were obtained in $10 \mathrm{~min}$ in the OP-HCR [66].

HC technologies have only recently gained significant attention compared to their ultrasonic analogues. Thus, the mechanisms of ultrasonic effects such as hot spots, mechanical and chemical effects induced by cavitation were adopted to interpret the roles of HC [67]. Actually, the mechanisms of $\mathrm{HC}$ effects are more complex than those of ultrasonic effects due to the complicated matrix of HC formation. Beside cavitation number, other hydrodynamic factors, such as inlet pressure, flow rate and velocities in the constrictions, $\alpha$ value (the ratio of total perimeter of the holes to the total area of the opening), and $\beta_{0}$ value (the ratio of total area of holes to the cross-sectional area of the pipe), etc., synergistic efficiency $[68,69]$.

\subsubsection{Venturi Tubes}

As one of the most common restricting structures, Venturi tubes can also induce HC in a flowing-fluid system (Figure 2) [40], which is very suitable for industrial scale applications [70]. 
According to Bernoulli's equation, the very high energy dissipation rate and turbulent intensities are realized at high inlet pressure and conforming pressure drops across the Venturi-throat (constriction part). This, in turn, makes cavity-cluster collapse more violent [65]. Venturi-HCRs can therefore be used to produce free radicals to oxidize organic contaminants [70,71]. Moreover, the yield of the free radicals generated in Venturi-HCRs dominates the oxidation rate. Thus it can be used to measure the cavity-collapse intensity [72].

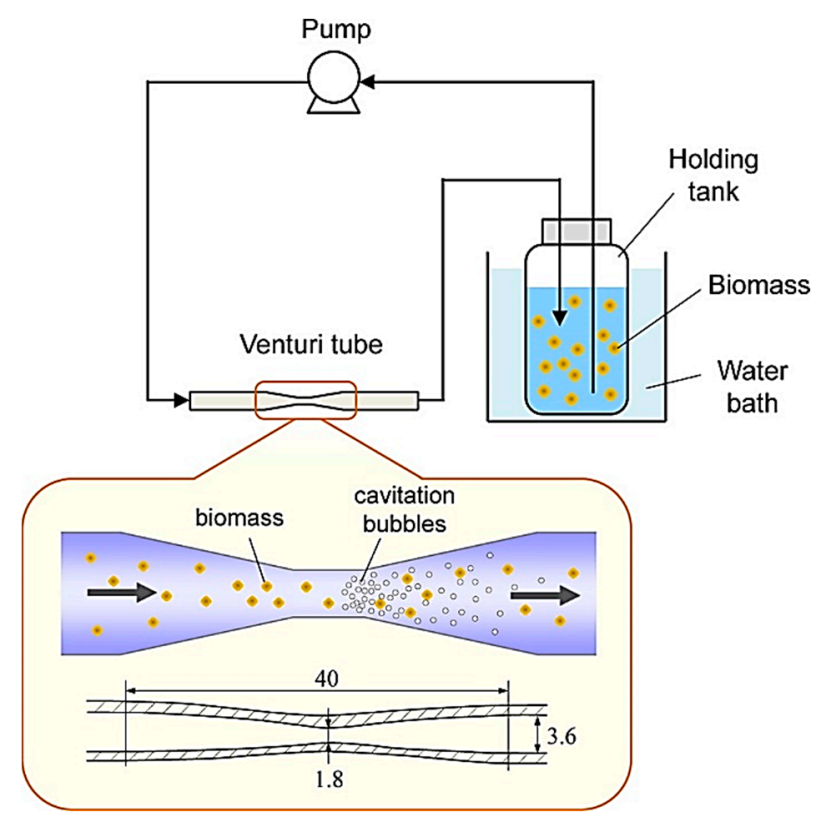

Figure 2. Venturi tube HCR. (Reproduced with permission from Nakashima et al. [40]).

Their cavitational effects mean that Venturi-HCRs are also suitable for use in water disinfection [73,74], the intensification of biodiesel synthesis [75], the pre-treatment of LCB for lignin removal and glucose and xylose formation [40]. The throat diameter, throat/length ratio, throat velocity and cavitation number are generally the main factors that determine the efficacy of Venturi-HCRs $[40,65,73]$.

Compared with OP-HCRs, the large bubble clouds formed in Venturi flow negatively affect the cavitational yield, since stronger interactions between cavitation bubbles result in inter-bubble coalescence and the recombination of the free radicals generated during cavitation collapse [74,76,77]. This is a significant feature of supercavitating flow regimes and choked flow. In supercavitation, the superabundant bubbles occupy the whole flow cross-section and cause the discontinuum of the liquid flow [78]. As OP-HCRs, it is insufficient only using the cavitation number to state the cavitation conditions. In fact, the geometry of Venturi tubes, gas content, temperature, flow velocity, and even surface roughness can influence the cavitational efficiency [78]. Despite these limitations, Venturi-HCRs can easily be scaled-up to create high-throughput systems with lower energy consumption for industrial applications $[70,75,79]$.

\subsubsection{High-Pressure Nozzles (Microfluidizers)}

Microfluidizers are another special type of OP-HCR. It creates effective cavitation via a threshold of upstream high-pressure nozzle pressure ( $>15 \mathrm{MPa}$ ) [80]. HC is mechanically generated within the high-pressure fluid system via an extreme high pressure drop (Figure 3) $[47,80]$. The cavitation number $\sigma$ is calculated in the high-pressure fluid system [80]:

$$
\sigma=\frac{p_{d}-p_{v}}{p_{u}-p_{d}} \approx \frac{p_{d}}{p_{u}}
$$


where $p_{d}, p_{u}$, and $p_{v}$ present the downstream pressure, upstream pressure, and vapour pressure, respectively. The $\sigma$ value should drop with the rising upstream pressure, leading to more cavitation events. In order to reach high pressure (e.g., $240 \mathrm{MPa}$ ), microfluidizers are generally equipped with a fine nozzle $(80 \mu \mathrm{m}$ diameter in Figure 4) [44].

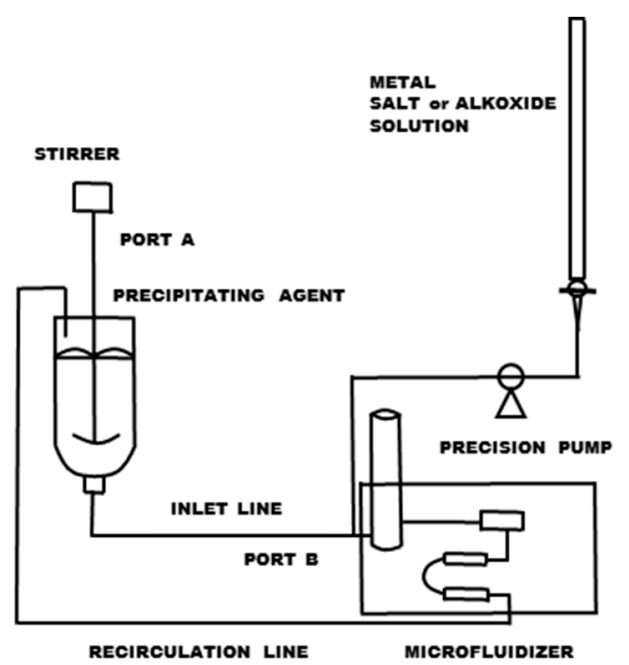

Figure 3. Schematic of a microfluidizer and its cavitational chamber. (Reproduced with permission from Sunstrom IV et al. [47]).
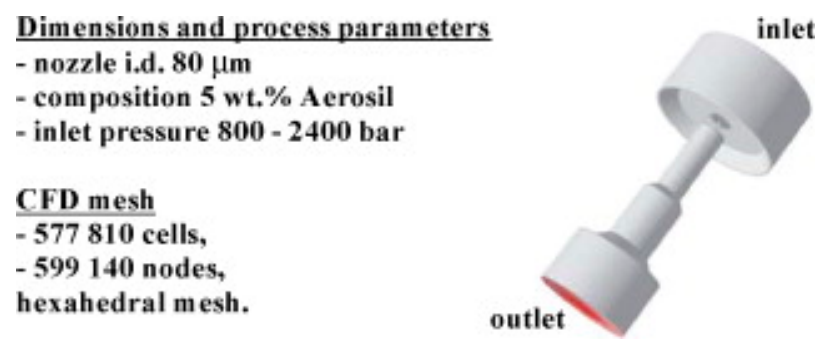

Figure 4. Presentation of the high-pressure nozzle disintegrator. (Reproduced with permission from Bałdyga et al. [44]).

The large pressure drop leads to the formation and collapse of bubbles, causing localised solvent heating and the formation of ultra-speed cumulative microjets [42,47]. The micro-strain in the materials is caused by the high cavitational and shear forces, in which the Reynolds and cavitation numbers are key factors [45]. Therefore, microfluidizers have mainly been used to produce nanostructured materials, such as metal oxides and supported metals whose grain sizes can be in the 1-20 nm range [46-48]. The cavitational state can be altered by simple mechanical regulation to moderate the properties of superfine and fine particles, which are formed by the mechanical breaking of weak intermolecular bonds in suspensions and emulsions [42,45].

The formation of hydroxyl radicals in the microfluidizer means that hydrodynamic stresses and cavitational effects play synergistic roles [71]. Microfluidizers have so far been used for the intensification of emulsification, dispersion, dissolution, extraction, chemical reactions, as well as sterilisation, etc., thanks to their mechanical and chemical effects $[42,80]$.

\subsection{Rotor-Stator HCRs}

Rotor-stator homogenisers, which are characterised by their greatly localised energy dissipation, are extensively applied for reducing the size of dispersed phases and reactive mixing $[57,81]$. One advantage of the RSD is that one may easily realize the scale-up, meanwhile avoiding the 
orifices blockage with particles or viscous components occurred in traditional OP-HCRs. Owing to its compact design, a smaller installation space is demanded to directly ensure overall safety [54].

The mechanical processing of materials in the liquid-phase, such as the breakage of nanoparticle clusters, microorganism cell disruption, and the emulsification of immiscible mixtures with RSD, can be attached to the combined HC effects in narrow gaps between rotor and stator [52]. Micro-turbulence induced by HC significantly intensifies the mass transfer in heterogeneous system and enlarges contacts among substrates and media [54,57]. The physical and chemical mechanisms of rotor-stator mixers can be explained in terms of the breakage of nanoparticle clusters, microorganism cell disruption and the emulsification of immiscible mixtures.

\subsubsection{Breakage of Nanoparticle Clusters}

The Silverson 150/250 MS RSD contains a rotor with 4-inner blades and 8-outer blades and two disintegrating stators with holes, as shown in Figure 5 [82].

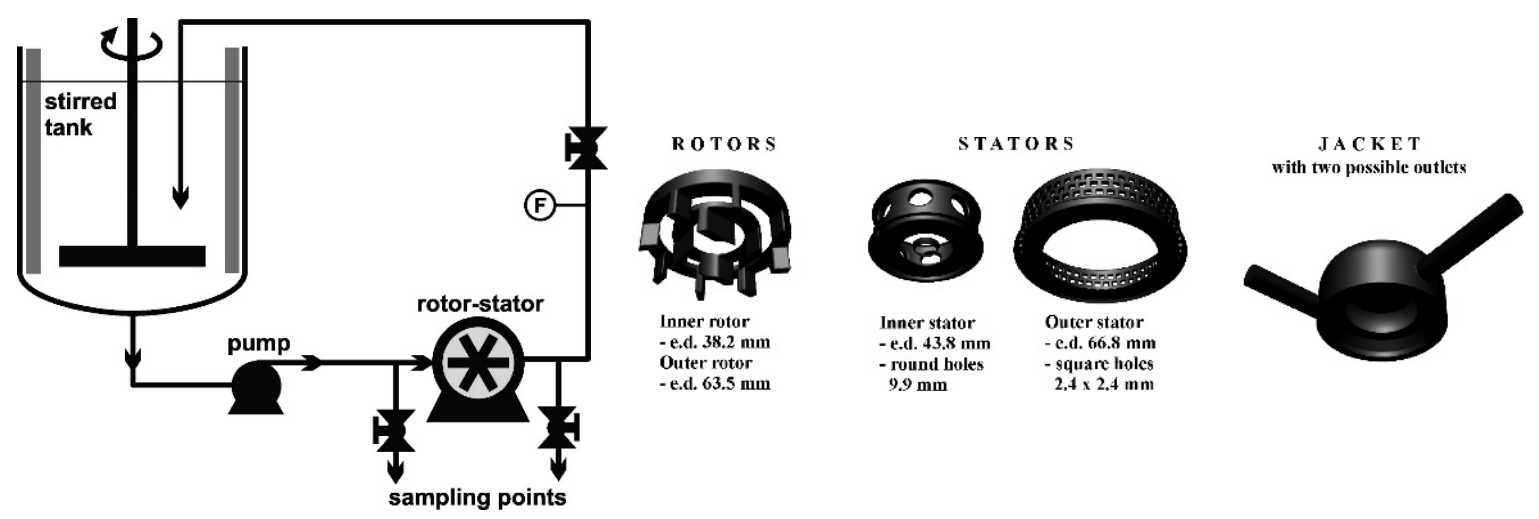

Figure 5. Schematic of rotor-stator mixer and its geometry. (Reproduced with permission from Bałdyga et al. [82]).

In RSD, very high hydrodynamic stress is generated to prepare the long-standing nanosuspensions by shattering nanoparticle clusters (disintegration of Aerosil $200 \mathrm{~V}$ agglomerates). The hydrodynamic stress generated by fluid deformation, inertia and cavitation differs with the flow field. At $9000 \mathrm{rpm}$, the smallest local pressure value is $59 \mathrm{kPa}$, which is over the saturated vapour pressure, meaning that less or no cavitation effects occur in rotor-stator simulations $[43,44]$.

In contrast, the oxidation of KI via oxidants formed by cavitational effects was achieved in aqueous solutions using a barrel RSD (Figure 6) [52], indicating that cavitational events may occur at the pits and rotor surface. The rotation speed of the rotor dominates the shear rate and pressure area. The shear rate increases linearly as the rotational speed increases, but the area of the high shear zone shrinks [52].
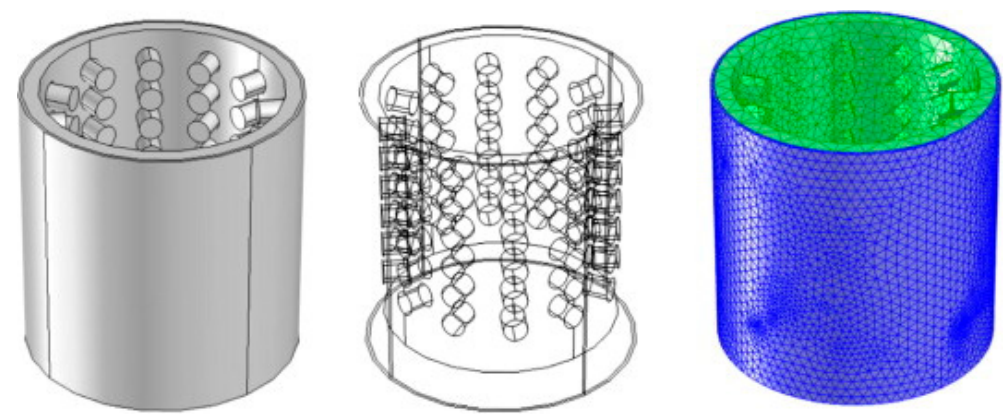

Figure 6. Barrel RSD. (Reproduced with permission from Badve et al. [52]). 


\subsubsection{Microorganism Cell Disruption}

A vertical RSD with 58-80 rotor vanes and 8-16 stator vanes was designed for parametric analyses at 2400-3000 rpm of rotation rate (Figure 7). Its energy efficiency is up to two orders of magnitude higher for water disinfection (inactivation of E. coli and E. faecalis) using RSD than other cavitation devices. Moreover, a smaller gap between rotor and stator induces high shear forces in the constriction, which causes rapid colony disaggregation and the damage of individual cells. In addition, the angular velocity and number of contractions/expansions significantly affect inactivation efficiency [50].
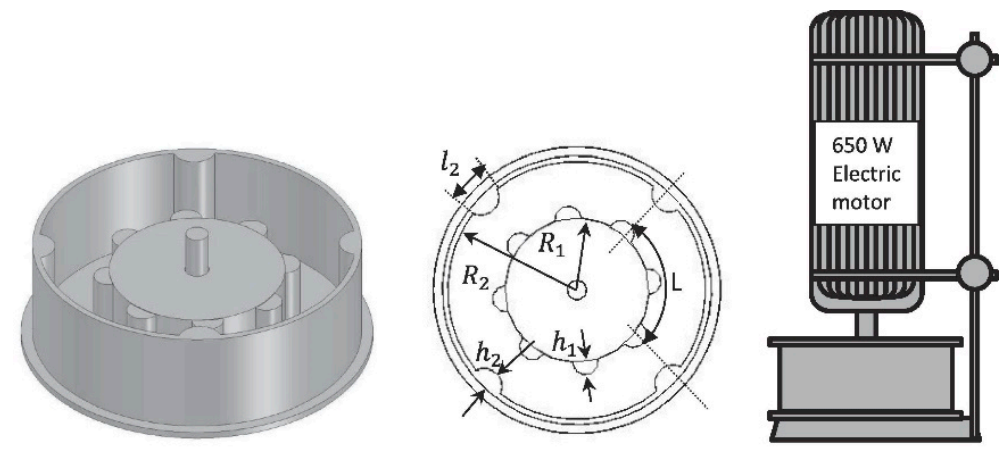

Figure 7. Vertical RSD setup. (Reproduced with permission from Cerecedo et al. [50]).

The strong shock waves at high hydrostatic pressures induce extraordinary release of intracellular components [50], and the coagulation of cytoplasmic matter in the liquid [83]. Moreover, the lack of matter in the periplasmic space may indicate the role of local high temperatures during cavitational bubble implosions [50,84].

The cavitational mechanism and flow field in a RSD have been analysed with a high-speed camera at various rotor rotational speeds (2700-3600 rpm) and pump pressures $(0.0-0.15 \mathrm{MPa})$ (Figure 8). Numerous cavitation bubbles and cavitation cloud separation (shedding) were clearly observed during the interaction between the rotor and stator. In such high-intensity separation regions, cavitation bubbles were produced as the pressures decreased under the saturated vapour pressure [51]. The microorganisms rupture under shear forces with the powerful turbulence flow [57].

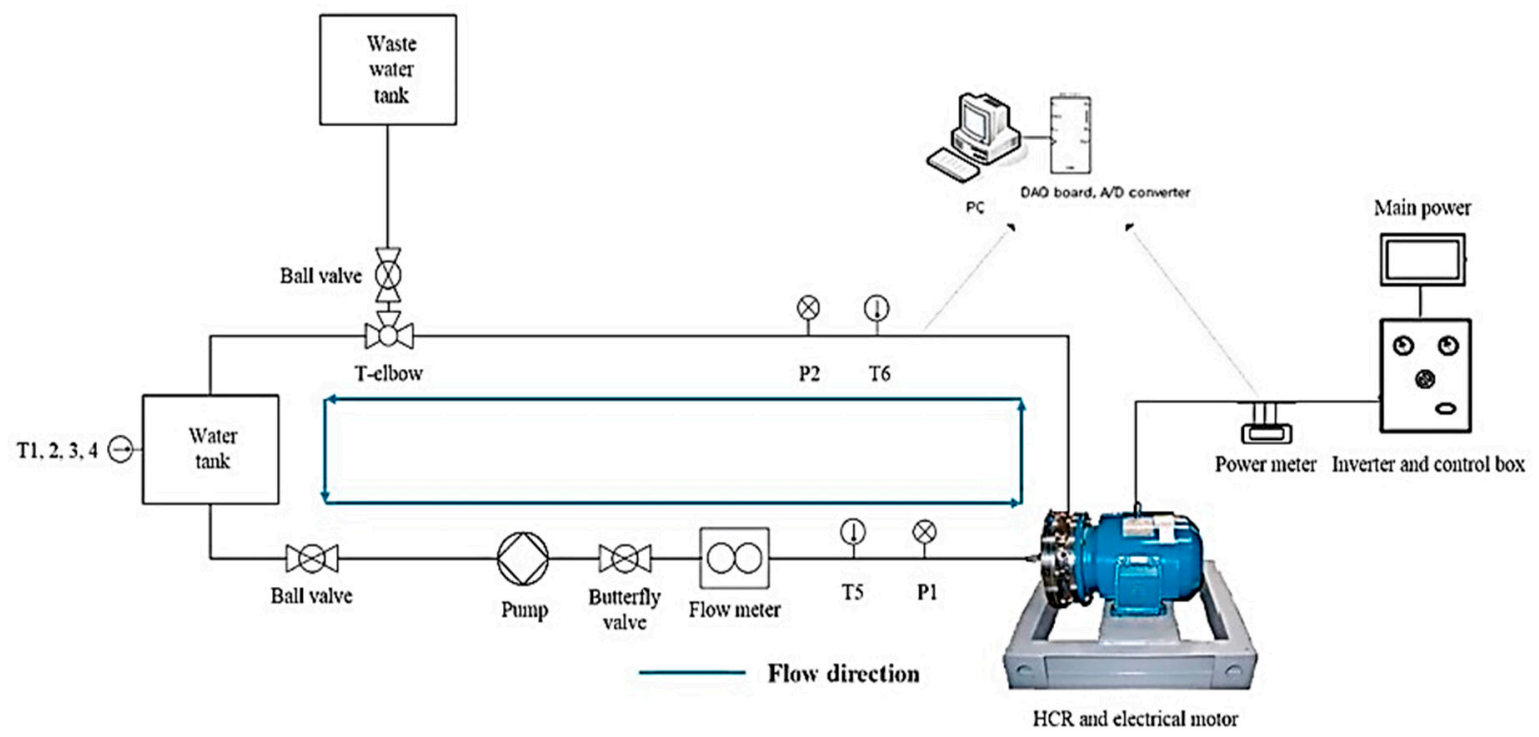

Figure 8. Horizontal RSD setup. (Reproduced with permission from Sun et al. [51]).

The treatment rate using this RSD is extremely higher and the cost is relatively reasonable compared with previous HCRs studies [51]. 


\subsubsection{Emulsification of Immiscible Mixtures}

The improvement of mass transfer using RSD can be demonstrated by measuring droplet sizes during the emulsification of immiscible phases. Emulsions (W/O and $\mathrm{O} / \mathrm{W})$ have been prepared at rotational speeds of 5000 and 25,000 rpm using a Virtishear rotor/stator homogeniser (Virtis, Templest IQ, Figure 9). The shear forces generated in the cavitation zone between the rotor and the stator dominate the emulsion droplet size [56].

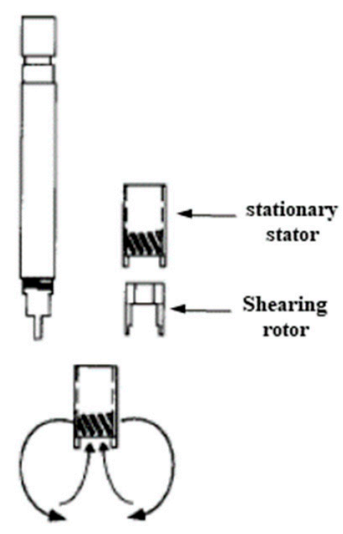

Figure 9. Schematic representation of the configuration of a rotor/stator homogeniser. (Reproduced with permission from Maa and Hsu [56]).

The flow becomes very turbulent with swirls of various scales at high speed rotation and agitation [56], resulting in powerful shear forces via the motion of turbulent flow [85]. The smaller micro-swirls are most effective on the surface of these liquid drops [85,86], which break to smaller drops. Thus the size of droplets decreases with increasing homogenisation power, rotational speed and processing time [56].

Continuous RSD (Figure 10) has been applied in triglyceride transesterification for biodiesel production. The micron-sized droplets of the immiscible of lipid and alcohol are formed by the high speed rotation of rotors leading to superior heat and mass transfer, thus the rate of the transesterification greatly rises in contrast to traditional stirring methods [54].
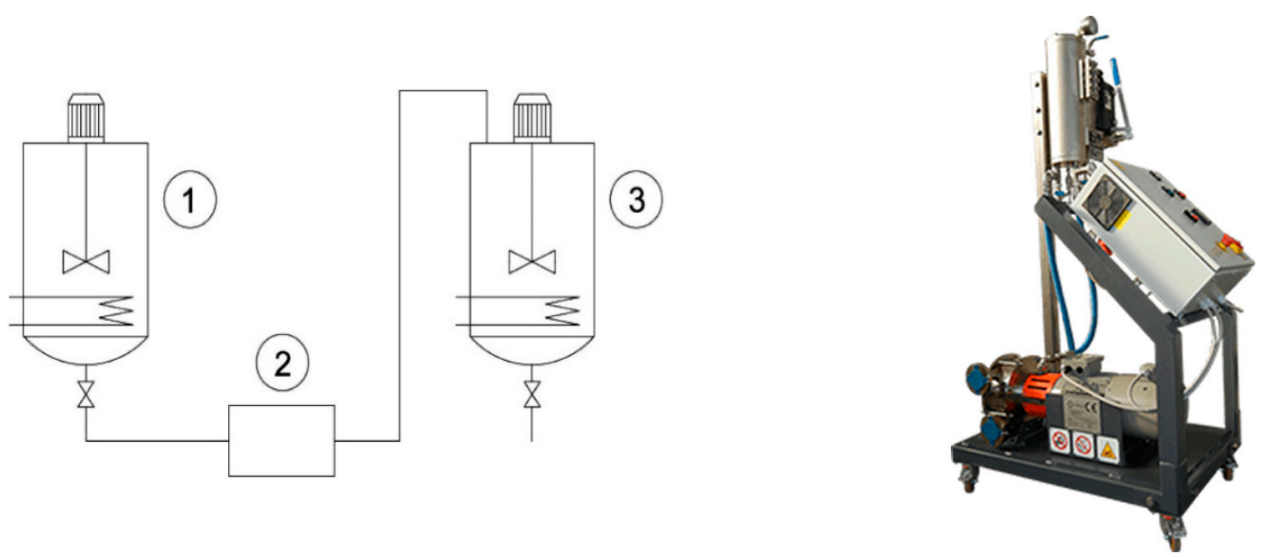

Figure 10. Pilot apparatus of HC: (1) Feed tank, (2) Rotor-stator unit, (3) Collector tank. (Reproduced with permission from Crudo et al. [54]).

A fatliquor precursor for the application in the leather has been prepared using the same RSD via the oxidation/polymerisation of waste plant oils at $90^{\circ} \mathrm{C}$, enabled long-standing emulsification with water in absence of surfactants. A four-fold reduction in waste-oil oxidation time was achieved by using the cavitational techniques. The results all indicate that the very effective RSD is well-matched to a scale-up process [53]. 
Furthermore, RSD has been used to carry out the mechanical activation of blends of starch hydrogel and synthetic copolymer latex. The thermostatic chamber contains a stator, a rotor and the cylindrical rings with rectangular channels. Preliminary mechanoactivation consistently improved the compatibility of the components, while the amorphous phase ordering of the composite and the crystallisation of starch were promoted at $5000 \mathrm{rpm}$ for 4-10 s. The elasticity of the samples increased with increases in starch content [57].

\section{Extraction with HC Reactors}

\subsection{Extraction of Bioactive Compounds and Antioxidants from Plants}

Antioxidants, including endogenously synthesised compounds, externally derived antioxidant nutrients and "non-nutrient" antioxidants, play an important role in reducing the oxidative damage of free-radicals [87]. As enabling technologies, microwaves [88] and ultrasound [89,90] have frequently been employed to extract bioactive compounds and antioxidants, since 2000, to improve efficiency and product quality. The introduction of cavitation facilitates the disruption of cells for the improved release of cellular contents. Although ultrasound-assisted extraction (UAE) is usually used to recover various natural products, HCE is considered as an appropriate alternative. Importantly, HCE has proven itself to be highly effective for the extraction on large scales [6]. The extraction materials, methods and effective factors in various HCRs are briefly discussed below.

The efficiencies of cocoa-bean-shell extraction using UAE and RSD have been compared [4]. The hydrophilic product contains polyphenols and methylxanthines, while the lipid layer was simultaneously obtained using either $70 \%$ ethanol or a co-solvent of water/ethanol/hexane. $25 \mathrm{~L}$ of slurry with a 1:10 solid/solvent ratio was processed in the RSD with $3000 \mathrm{rpm}$ at room temperature for $11 \mathrm{~min}$. Higher theobromine and total phenolic content (TPC) were achieved using RSD than with UAE at $19.9 \mathrm{kHz}$ and $150 \mathrm{~W}$ (Table 1).

As listed in Table 1, the higher yield of recovering fats using RSD was also achieved compared to that by UAE. The valuable components, such as caffeine, theobromine, antioxidant flavanols and cocoa butter, were extracted conveniently. The comparable autoxidation characterized with radical scavenging activity (DPPH EC50) and Trolox Eq. were achieved by using either UAE or RSD [4].

A Venturi-shaped hydraulic loop HCR with a centrifugal pump (4.9-7.5 kW, $2900 \mathrm{rpm})$, and $120 \mathrm{~L}$ of biomass slurry $(0.44 \% w / w$ dry basis) have been used to produce aqueous solutions of silver fir needles (Abies alba Mill. collected in northern Tuscany, Italy) for 60-90 min, resulting in comparable or higher in-vitro DPPH and ORAC antioxidant activities than those of reference substances, such as pure extracts, other water extracts and beverages. TPC and flavonoid contents increased with both temperature and processing time below $47^{\circ} \mathrm{C}$ [5]. Integrated $\mathrm{HC}$-vacuum extraction equipment was used to extract polyphenols from green tea [20]. Negative pressure cavitation (NPC) is also considered as a kind of HC. In this form, the negative pressure dominates the cavitation effects by a vacuum pump, and the turbulence throughout the reactor is retained by airflow [6]. The maximal extraction efficiency $(28.2 \%)$ was obtained under the optimal extraction conditions (80\% of ethanol concentration, 20/1 liquid/solid ratio, at $73{ }^{\circ} \mathrm{C}$ for $28.7 \mathrm{~min}$ ) [20]. In addition, NPC extraction was more effective for the extraction of heat-sensitive compounds compared with UAE [6].

Furthermore, the micronisation of ginkgo flavonoids may be employed in drug delivery systems to improve drug absorption. The yield of ginkgo flavonoids from ginkgo biloba leaves reached about $37.5 \%$ by using supercritical carbon dioxide extraction with ethanol at $20 \mathrm{MPa}$ and $40^{\circ} \mathrm{C}$ for $90 \mathrm{~min}$. After extraction, the microparticles of ginkgo flavonoids were achieved with supercritical fluid atomisation under the assistant of a HC mixer. The atomisation of the mixing solution was carried out through a nozzle, which allows for a localised pressure drop, leading to the cavitation effects. Thus the spherical particle sizes can be controlled and 0.2-3.0 $\mu \mathrm{m}$ particles were successfully gained [91]. 
Table 1. Comparison of extracted yields of theobromine and caffeine content, TPC, antioxidant activity and fatty acid methyl esters (fats) from the raw cocoa shells with the 30:49:21 Hexane/EtOH/ $\mathrm{H}_{2} \mathrm{O}$ mixture between using UAE and RSD. (Reproduced with permission from Grillo et al. [4]).

\begin{tabular}{|c|c|c|c|c|c|c|c|c|c|c|}
\hline \multirow[b]{3}{*}{ Method } & \multicolumn{8}{|c|}{ Hydro-Alcoholic Phase } & \multirow{2}{*}{\multicolumn{2}{|c|}{$\begin{array}{c}\text { Hexane Phase } \\
\text { Fats }\end{array}$}} \\
\hline & \multicolumn{2}{|c|}{ Theobromine } & \multicolumn{2}{|c|}{ Caffeine } & \multicolumn{2}{|c|}{ TPC } & \multirow{2}{*}{$\begin{array}{c}\text { DPPH } \\
\text { EC50 } \\
\mu \mathrm{g} / \mathrm{mL}\end{array}$} & \multirow{2}{*}{$\begin{array}{c}\text { Trolox Eq. } \\
\mu \mathrm{mol} / \mathrm{g} \\
\text { extract }\end{array}$} & & \\
\hline & $\begin{array}{l}w / w \% \\
\text { extract }\end{array}$ & $\begin{array}{l}\mathrm{mg} / \mathrm{g} \\
\text { shells }\end{array}$ & $\begin{array}{l}w / w \% \\
\text { extract }\end{array}$ & $\begin{array}{l}\mathrm{mg} / \mathrm{g} \\
\text { shells }\end{array}$ & $\begin{array}{l}\mathrm{mg} / \mathrm{g} \\
\text { extract }\end{array}$ & $\begin{array}{l}\mathrm{mg} / \mathrm{g} \\
\text { shells }\end{array}$ & & & $\begin{array}{l}w / w \% \\
\text { extract }\end{array}$ & $\begin{array}{l}\mathrm{mg} / \mathrm{g} \\
\text { shells }\end{array}$ \\
\hline UAE & 5.04 & $7.02 \pm 0.11$ & 0.81 & $1.13 \pm 0.09$ & 51.1 & 7.1 & $76.9 \pm 3.6$ & $204.7 \pm 9.6$ & 91.7 & 23.2 \\
\hline RSD & 9.25 & $13.5 \pm 0.16$ & 0.75 & $1.09 \pm 0.12$ & 79.9 & 11.7 & $72.1 \pm 4.1$ & $218.3 \pm 12.4$ & 94.3 & 95.0 \\
\hline
\end{tabular}

Note: TPC: Total phenolic content; DPPH EC50: The ability of the extracts to scavenge at $50 \%$ of the DPPH (1,1-diphenyl-2-picrylhydrazyl radical); Trolox Eq.: The antioxidant activity was quantified relative to a soluble vitamin E analogue (Trolox).

\subsection{Lipid Extraction from Microorganisms}

The production of renewable energy resources such as biodiesel and biogas via the complex treatment of cyanobacteria biomass is a sustainable strategy. HC-based technologies can increase the efficiency of inedible fat extraction [92], since cell disruption is mainly restrained to the cell wall and membrane [9]. Given its energy efficiency, comparable extractability, and scale-up potential, HC may become an industrial-scale method for microalgae extraction [21]. A series of orifice plates with $\alpha=2.5 \%$ to $10 \%$ and $\beta_{0}=1 \%$ to $10 \%$ has been designed in order to optimise the extraction of lipids in wet microalgae. The main HC parameters, such as cavitation number, $\alpha$ and $\beta_{0}$ values, profoundly affect extraction efficiency. Maximum lipid extraction (ca. $46.0 \%$ ) was obtained at $5 \%$ values of both $\alpha$ and $\beta_{0}$ [22].

A Venturi-HCR has been used to treat a mixture containing $5 \mathrm{~g}$ dry weight of Nannochloropsis sp. within methanol/hexane $(20.5 \mathrm{~mL} / 47.5 \mathrm{~mL})$ at $34{ }^{\circ} \mathrm{C}$ and 6.8 bar of sample chamber pressure. HCE is more rapid than the agitation method at 260 and $1000 \mathrm{rpm}$. A lipid yield of $8.9 \%$ was achieved by HCE in $10 \mathrm{~min}$, while $5.44 \%$ and $7.3 \%$ yields were achieved in $60 \mathrm{~min}$ by stirring at 260 and $1000 \mathrm{rpm}$, respectively. The volumetric mass transfer coefficients of HCE was 7.373/s, while those of agitation were 0.534 and $0.121 / \mathrm{s}$ at $1000 \mathrm{rpm}$ and $260 \mathrm{rpm}$ stirring speeds, respectively. According to the thermodynamic parameters, $\Delta \mathrm{H}^{\circ}(20.72 \mathrm{~kJ} / \mathrm{mol}), \Delta \mathrm{S}^{\circ}(58.05 \mathrm{~J} / \mathrm{mol} / \mathrm{K})$ and $\Delta \mathrm{G}(1.969-3.013 \mathrm{~kJ} / \mathrm{mol}$ at $\left.34-50{ }^{\circ} \mathrm{C}\right)$, the process of lipid extraction was considered to be endothermic, non-spontaneous and irreversible, indicating that more energy was consumed compared to the extraction from other oil plant sources [8]. In a similar study, a closed-type $0.9 \mathrm{~L} \mathrm{HCR}$ with an orifice plate $(0.5 \mathrm{~mm} \times 13$ holes in radial pattern) was fabricated for the lipid extraction from wet microalgae Nannochloropsis salina with hexane $(1: 0.8 v / v)$. A higher lipid yield was observed by using HCE compared to using autoclave and via ultrasonication. The highest lipid yield reached $45.5 \%$ by using $0.89 \%$ sulfuric acid at $0.4 \mathrm{MPa}$ inlet pressure in $25 \mathrm{~min}$ [21].

In a pilot-scale study, a loop HCR with an orifice plate $(1 \mathrm{~mm} \times 33$ holes in radial pattern $)$ was used to extract lipids from Tetraselmis suecica suspensions (40 L seawater containing $0.9 \mathrm{~kg}$ of the dry algae). As a result, HCR was shown to have $3 \mathrm{MJ} / \mathrm{kg}$ of specific energy consumption, indicating that HCR is much more efficient than UAE. Although HC can sufficiently injure the cell wall to leave solvents diffusion for lipid extraction, it still accounts for about $13 \%$ of the total biomass energy, which is too high for the biofuels production [9]. Similarly, lipids in microalgae Nannochloropsis sp. were extracted with co-solvent of hexane and methanol within a HCR. Under the optimum conditions, the specific energy consumption reached $16.743 \mathrm{MJ} / \mathrm{kg}$ lipid [11].

\subsection{Delignification of Lignocellulosic Biomass}

Producing biofuels from sustainable lignocellulosic feedstocks is a promising means of meeting energy requirements. The three processing steps for the valorisation of LCB are: pre-treatment to remove lignin, cellulosic hydrolysis for producing sugars, and further fermentation to obtain 
bioethanol [1]. HC technology to intensify LCB pre-treatment is an alternative strategy that has been offered for assimilation into biorefineries [1,29]. The purpose is to explore a green strategy for the applications of LCB [93]. For example, a RSD has been used to enhance the delignification efficiency of wheat straw that was pre-treated with alkali. The tensile index of the synthesised paper sheets increased by $50 \%$ to $55 \%$ after $10-15$ min of treatment. Moreover, RSD is more effective than other delignification techniques in aspect of processing time and electrical consumption [25].

The sugarcane bagasse (SCB) was efficiently treated under alkaline conditions by using a loop HCR with an orifice plate $(1 \mathrm{~mm} \times 27$ holes in radial pattern). In the $100 \mathrm{~mL} \mathrm{HCR}$, a cloth mesh cylinder (40 mesh) with the SCB powders $(1.18-1.70 \mathrm{~mm}$ ) was put in the cavitation zone. Under optimal conditions ( $0.48 \mathrm{M} \mathrm{NaOH}$, solid/liquid ratio $4.27 \%$, and $0.3 \mathrm{MPa}$ inlet pressure), $52.1 \%$ of glucan content, $60.4 \%$ of lignin subtraction and $97.2 \%$ of enzymatic digestibility were attained at $23-64{ }^{\circ} \mathrm{C}$ in $45 \mathrm{~min}$. Moreover, the hydrolytic yields of the pre-treated SCB reached $82 \%$, that was $30 \%$ higher compared to the untreated controls [94]. With another loop orifice-HCR ( $1 \mathrm{~mm} \times 16$ or 27 holes in radial pattern, Figure 11), a cloth mesh cylinder (18 mesh) with the SCB powders $(4.70 \mathrm{~mm})$ was put in a $1 \mathrm{~L}$ reactor. Under the optimal conditions $\left(0.3 \mathrm{M} \mathrm{NaOH}, 0.3 \mathrm{MPa}, 70^{\circ} \mathrm{C}\right)$, the hydrolytic yields for cellulose and hemicellulose reached $93.1 \%$ and $94.5 \%$, respectively. Moreover, similar efficiencies were achieved with various orifice plates $(1 \mathrm{~mm} \times 16$ and 27 holes with corresponding cavitation numbers of 0.017 and 0.048 , respectively) over $10 \mathrm{~min}$ of pre-treatment [38].

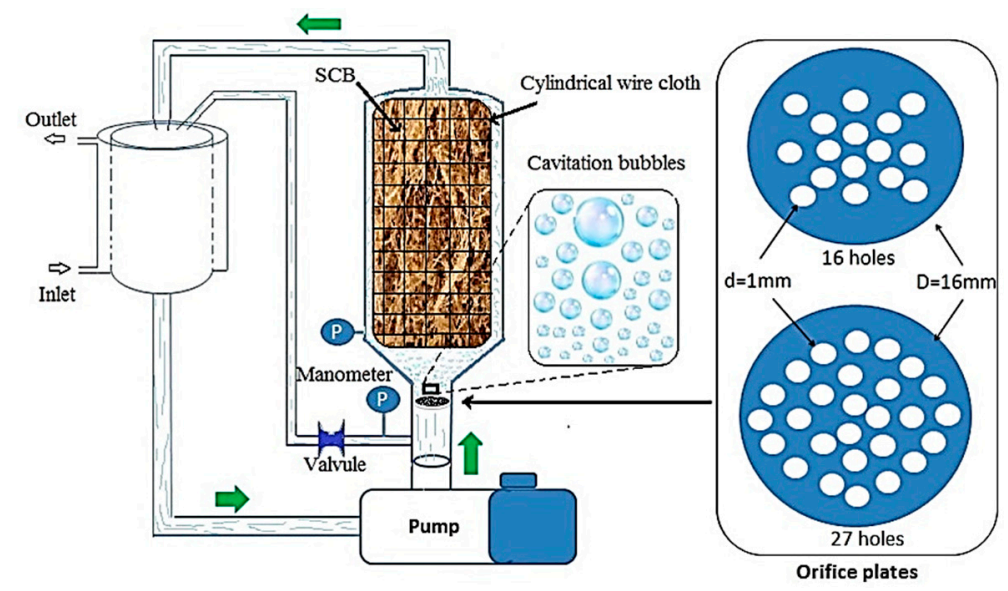

Figure 11. HC system for SCB pre-treatment. (Reproduced with permission from Terán Hilares et al. [38]).

In addition, $\mathrm{NaOH}-\mathrm{H}_{2} \mathrm{O}_{2}$ can also be used for SCB-based biorefineries in a loop HCR with an orifice plate $(1 \mathrm{~mm} \times 16$ holes in a radial pattern with a cavitation number of 0.017$)$. A total of $20 \mathrm{~g}$ of SCB powders were processed in a $3 \mathrm{~L} \mathrm{HCR}$. Cellulosic-fraction digestibility $(95.4 \%)$ was achieved at $0.3 \mathrm{MPa}$ inlet pressure in about $10 \mathrm{~min}$ with $0.29 \mathrm{M} \mathrm{NaOH}$ and $0.78 \% \mathrm{H}_{2} \mathrm{O}_{2}(v / v)$. After fermentation by Scheffersomyces stipitis NRRL-Y7124, 31.5 g ethanol were obtained from $1 \mathrm{~L}$ bulk liquid [95]. Corncob powders $(\leq 212 \mu \mathrm{m})$ have been processed for delignification with enzyme laccase from a microbial source (Trametes versicolor) in a $6 \mathrm{~L}$ loop HCR with two kinds of orifice plate (OP1: $2 \mathrm{~mm} \times 9$ and OP2: $3 \mathrm{~mm} \times 4$ holes in a radial pattern). As a result, $47.4 \%$ of the lignin reduction was achieved with OP1 after $60 \mathrm{~min}$ with the optimal conditions. The cavitational yield and energy consumption were less than those of other pre-treatment methods. However, the orifice plate was obstructed with a high corncob-slurry biomass loading rate $(>6.75 \%)$ [24]. Similarly, $16 \mathrm{~g}$ of corn stover powder $(<250 \mu \mathrm{m})$ was added in $400 \mathrm{~mL}$ of the $0.4 \mathrm{M} \mathrm{Na}_{2} \mathrm{CO}_{3} / 0.6 \mathrm{M} \mathrm{H}_{2} \mathrm{O}_{2}$ solutions, and the slurry was then circulated for $1 \mathrm{~h}$ at $30^{\circ} \mathrm{C}$ within a Venturi tube HCR (40 mm length; $3.6 \mathrm{~mm}$ internal diameter; $1.8 \mathrm{~mm}$ throat diameter). Compared with an UAE pre-treatment method, HCR was found to give a similar removal extent to lignin, but the HCR had higher efficiency for glucose and xylose production [40]. 
Besides the production of bioethanol, HCR can also perform the digestion of lignocellulosic "waste" to accelerate the process of biogas production. In biogas fermentation after the treatment of straw cuts with a HC process, the methane concentration from the concentrate reached an average value (58\%) in the biogas from waste. However, from the filtrate the methane content was $87 \%$ in the biogas, which is a superior result for the HC process [96]. The similar biomass solubilisation has been achieved using ultrasonic and HC pre-treatment for the mesophilic anaerobic co-digestion of wheat straw and cattle manure. The results show that the shorter pre-treatment time and the lower energy were required in the $\mathrm{HC}$ process as compared to the ultrasonic pre-treatment. The biogas production rate for HCR was $194 \mathrm{~mL} / \mathrm{mg}$, which is higher than that $(177 \mathrm{~mL} / \mathrm{mg})$ of the ultrasonic pre-treatment. However, biogas productivity via ultrasound was higher than that of the HC pre-treatment. Neither method was able to increase the methane concentration in the biogas [97].

\section{Case Study for Extracting Polyphenols from Basil}

We include herein a case study where experimental tests have been performed using a ROTOCAV cavitator developed by E-PIC S.r.l. [98]. The unit achieves controlled HC by forcing fluids and mixtures through a RSD. Besides being successful in treating liquids, for example to produce biodiesel [54], or to speed up liquid-gas reactions [53], the ROTOCAV cavitator can also be used to treat solid-liquid mixtures, due to its particular geometry.

This RSD is made up of several channels of different shapes, which are periodically aligned during high speed rotation of the rotor; the processed fluid or mixture is accelerated in both radial and axial directions inside the cavitation chamber and, flowing through the free channels, it is subjected to pressure waves, resulting in cavitation. The distinctive feature of this RSD is that it maximises the cavitation volume inside the cavitation chamber, processing all of the mixture without a bypass. Moreover, the mixture is subjected to thousands of cavitational events, at the same time, and with the same energy input, unlike static elements.

During the extraction processes, the ROTOCAV cavitator generates several physical phenomena at the same time: mechanical and shear forces, agitation, microjets, cavitation, hot spots and shockwaves. Together, these are able to break cell membranes and to increase mass transfer, enhancing solvent access to the compounds of interest. High local temperatures and pressures are dynamically generated when bubbles collapse inside the medium and this is efficiently exploited to extract high added-value compounds from solid vegetable matrices. Matrix disintegration, increases in contact area and in porosity, coupled with intense mixing on the micro scale, ensure the optimisation of extraction yields in a continuous process [99].

This approach has therefore been used for the extraction of polyphenols from the leaves and stems of industrial leftovers of basil (Ocimum Basilicum L.), using water as the only solvent. The extraction efficiency was evaluated by measuring the yield, TPC and antioxidant capacity of the extracts and then comparing them with exhaustive extraction and UAE. The exhaustive extraction was carried out under reflux using $75 \%$ ethanol at $85^{\circ} \mathrm{C}$ for $4 \mathrm{~h}$, while the UAE was performed in an ultrasonic bath (Danacamerini, Turin, Italy) at $20 \mathrm{kHz}$ and $100 \mathrm{~W}$ for $15 \mathrm{~min}$ using water at around $45{ }^{\circ} \mathrm{C}$. Both procedures were performed with $10 \mathrm{~g}$ of fresh matrix and a 1:15 solid/liquid ratio. In a pilot-scale reactor, HC extraction was accomplished using $1000 \mathrm{~g}$ of sample and water (1:15 ratio) at $3000 \mathrm{rpm}$ for $15 \mathrm{~min}$, with an absorbed energy of $3.2 \mathrm{~kW}$ and a final temperature of $45^{\circ} \mathrm{C}$. After extraction, the extracts were filtered under vacuum and lyophilised for further analysis. TPC was assessed using the Folin-Ciocalteu test, while the same was done for antioxidant capacity using an ORAC assay.

The extraction yields obtained for leaf and stem basil in the different extraction procedures are presented in Figure 12. The exhaustive method showed a yield of $30.87 \%$ for the leaves and $25.87 \%$ for the stems. Similar values were obtained with UAE: $28.60 \%$ for leaves and $23.95 \%$ for stems. HCE performed on a large-scale gave lower extraction yields than the other procedures; $18.75 \%$ for leaves and $16.25 \%$ for stems. Although HCE gave lower extraction efficiency, it operated exclusively in water 
and was sixteen times faster than the exhaustive methods. Furthermore, a unique extraction cycle of $15 \mathrm{~min}$ on a large-scale achieved $187 \mathrm{~g}$ of extract per kg of dry material, meaning that, in $30 \mathrm{~min}$ (two extraction runs), it can recover more than the exhaustive method, which would give $308 \mathrm{~g}$ in $240 \mathrm{~min}$. Thus, the shorter extraction time of the HC process can lead to increased productivity. Moreover, it should be noted that the specific energy applied for HCE was lower than that applied for UAE: tests with UAE were performed with a specific energy $(2.5 \mathrm{kWh} / \mathrm{kg}$ of solid) of more than 3 times the energy of HCE $(0.8 \mathrm{kWh} / \mathrm{kg}$ of solid).

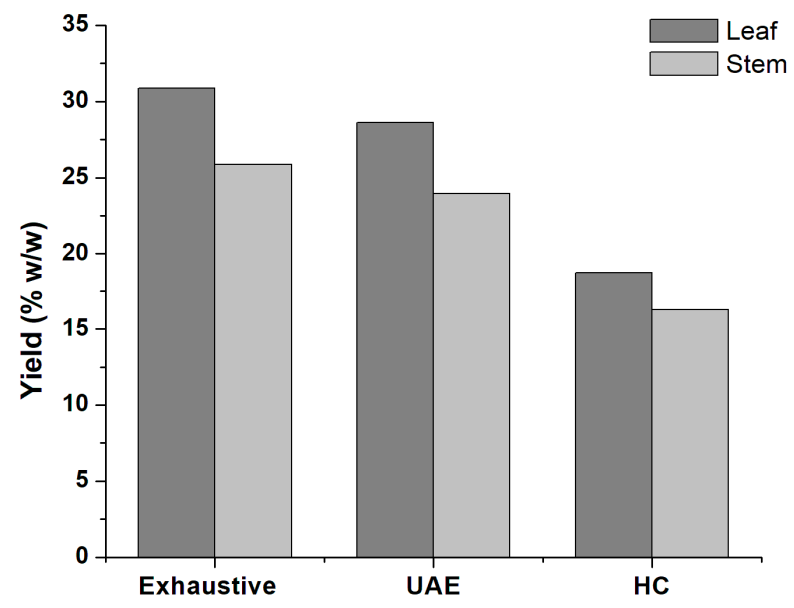

Figure 12. Yield results expressed as the dry weight obtained from leaf and stem extractions (UAE and $\mathrm{HC}$ in pure water).

The TPC and antioxidant capacities obtained from the extracts are shown in Table 2. The highest TPC extracted from the plant was achieved using the exhaustive extraction; $68.24 \mathrm{mg} / \mathrm{g}$ for the leaves and $50.23 \mathrm{mg} / \mathrm{g}$ for stems, followed by UAE with similar values $(66.44 \mathrm{mg} / \mathrm{g}$ from leaves and 49.65 $\mathrm{mg} / \mathrm{g}$ from stems). The HC method recovered $65 \%$ of TPC of the exhaustive method from the leaves $(44.01 \mathrm{mg} / \mathrm{g})$ and $80 \%$ from the stems $(40.43 \mathrm{mg} / \mathrm{g})$.

Table 2. Results of total phenolic content and antioxidant capacity from basil leaves and stems, expressed as dry material.

\begin{tabular}{ccccc}
\hline \multirow{2}{*}{ Sample } & \multirow{2}{*}{ Extraction Method } & \multicolumn{2}{c}{ Total phenolic Content } & Antioxidant Capacity \\
\cline { 3 - 5 } & & $\mathbf{m g} / \mathbf{g}$ Extract & $\mathbf{m g} \mathbf{g}$ Matrix & $\boldsymbol{\mu m o l ~ E T / g ~ M a t r i x ~}$ \\
\hline \multirow{3}{*}{ Leaf } & Exhaustive & 220.92 & 68.24 & 96.55 \\
& UAE & 232.30 & 66.44 & 79.15 \\
& HCE & 234.78 & 44.01 & 79.51 \\
\multirow{2}{*}{ Stem } & Exhaustive & 199.19 & 50.23 & 72.02 \\
& UAE & 207.31 & 49.65 & 71.39 \\
& HCE & 238.80 & 40.43 & 69.09 \\
\hline
\end{tabular}

Although HC extracted lower amounts of phenolics from the plant material, it was observed that the obtained extract was more concentrated, in terms of $\mathrm{mg}$ of polyphenols per $\mathrm{g}$ of extract. Thus, the phenolic content in the HC leaf extract was $234.8 \mathrm{mg} / \mathrm{g}$ of dried extract, and for the UAE and exhaustive extracts, it was 232.30 and $220.9 \mathrm{mg} / \mathrm{g}$, respectively. The same trend was observed for the stem extracts; the HC extract presented $238.80 \mathrm{mg} / \mathrm{g}$ of dried extract, followed by the UAE extract with $207.31 \mathrm{mg} / \mathrm{g}$ and the exhaustive extract with $199.9 \mathrm{mg} / \mathrm{g}$. The ORAC assay for the measurement of antioxidant capacity revealed that HC extracts had remarkable values. The leaf extract from this process presented as much antioxidant capacity as the UAE extract, with $79.51 \mu \mathrm{mol}$ ET/g DM from HC and $79.15 \mu \mathrm{mol}$ ET/g DM from UAE. The higher value of the exhaustive extract may be due to the use of ethanol as a solvent, which can assist in the recovery of several compounds. The antioxidant capacity obtained 
from the stem extract from $\mathrm{HC}$ was $69.09 \mu \mathrm{mol} \mathrm{ET/g} \mathrm{DM}$, which is a comparable value to those obtained using the UAE and exhaustive methods (71.39 and $72.02 \mu \mathrm{mol} \mathrm{ET} / \mathrm{g} \mathrm{DM}$, respectively).

In conclusion, HCE of polyphenols from basil gave extracts with high TPC and antioxidant capacity using only water in an easy, fast and economical process. This device has therefore shown itself to be a feasible alternative for the green extraction of natural products on large-scales. In several studies the huge industrial demand of green process intensification, could find in HC technology the best solution. The possibility to install compact HC units as implementation of existing extraction plants, represents a tremendous goal. The powerful effect of $\mathrm{HC}$ on plant matrices enables in most cases to replace ethanol and other organic solvents, with pure water. The remarkable energy saving, the short extraction time and the easy scalability of processes assisted by $\mathrm{HC}$, should pave the road to further industrial applications.

Author Contributions: Conceptualization, Z.W., D.C.; V.B. and G.C.; Methodology, D.F.F.; Formal Analysis, L.S.; Investigation, A.C., and D.C.; V.B.; Data Curation, Z.W and G.C.; Writing-Original Draft Preparation, Z.W and D.F.F.; Writing-Review \& Editing, G.C.; Supervision, Z.W and G.C.

Funding: This research was funded by the University of Turin (ricerca locale 2018) and the DFF was funded by Coordenacão de Aperfeiçoamento de Pessoal de Nível Superior, CAPES/PDSE/88881.188528/2018-01.

Conflicts of Interest: The authors declare no conflict of interest.

\section{References}

1. Joshi, S.M.; Gogate, P.R. Waste Biomass Management-A Holistic Approach. In Waste Biomass Management-A Holistic Approach; Singh, V.C., Kalia, L., Eds.; Springer: Cham, Switzerland, 2017; pp. 251-287.

2. Ragauskas, A.J.; Beckham, G.T.; Biddy, M.J.; Chandra, R.; Chen, F.; Davis, M.F.; Davison, B.H.; Dixon, R.A.; Gilna, P.; Keller, M.; et al. Lignin valorization: Improving lignin processing in the biorefinery. Science 2014, 344. [CrossRef]

3. Stevens, C.; Verhé, R. Renewable Bioresources: Scope and Modification for Non-Food Applications; John Wiley \& Sons: New York, NY, USA, 2004.

4. Grillo, G.; Boffa, L.; Binello, A.; Mantegna, S.; Cravotto, G.; Chemat, F.; Dizhbite, T.; Lauberte, L.; Telysheva, G. Cocoa bean shell waste valorisation; extraction from lab to pilot-scale cavitational reactors. Food Res. Int. 2019, 115, 200-208. [CrossRef] [PubMed]

5. Albanese, L.; Bonetti, A.; D'Acqui, L.P.; Meneguzzo, F.; Zabini, F. Affordable production of antioxidant aqueous solutions by hydrodynamic cavitation processing of silver fir (Abies alba Mill.) needles. Foods 2019, 8, 65. [CrossRef] [PubMed]

6. Panda, D.; Manickam, S. Cavitation technology-the future of greener extraction method: A review on the extraction of natural products and process intensification mechanism and perspectives. Appl. Sci. 2019, 9, 766. [CrossRef]

7. Seo, Y.H.; Lee, I.G.; Han, J.I. Cultivation and lipid production of yeast Cryptococcus curvatus using pretreated waste active sludge supernatant. Bioresour. Technol. 2013, 135, 304-308. [CrossRef] [PubMed]

8. Setyawan, M.; Mulyono, P.; Sutijan, S.; Budiman, A. Comparison of Nannochloropsis sp. cells disruption between hydrodynamic cavitation and conventional extraction. In MATEC Web of Conferences, Proceedings of the 2nd International Conference on Engineering and Technology for Sustainable Development (ICET4SD 2017), Yogyakarta, Indonesia, 13-14 September 2017; EDP Sciences: Les Ulis, France, 2018; Volume 154, p. 01023.

9. Lee, A.K.; Lewis, D.M.; Ashman, P.J. Microalgal cell disruption by hydrodynamic cavitation for the production of biofuels. J. Appl. Phycol. 2015, 27, 1881-1889. [CrossRef]

10. Lee, A.K.; Lewis, D.M.; Ashman, P.J. Disruption of microalgal cells for the extraction of lipids for biofuels: Processes and specific energy requirements. Biomass Bioenergy 2012, 46, 89-101. [CrossRef]

11. Setyawan, M.; Budiman, A.; Mulyono, P. Sutijan Optimum extraction of algae-oil from microalgae using hydrodynamic cavitation. Int. J. Renew. Energy Res. 2018, 8, 451-458.

12. Yusaf, T.; Al-Juboori, R.A. Alternative methods of microorganism disruption for agricultural applications. Appl. Energy 2014, 114, 909-923. [CrossRef]

13. Qian, E.W. Research approaches to sustainable biomass systems. In Research Approaches to Sustainable Biomass Systems; Tojo, T.S., Hirasawa, T., Eds.; Academic Press: Cambridge, MA, USA, 2014; pp. 181-204. 
14. Binod, P.; Pandey, A. Chapter 1-Introduction. In Pretreatment of Biomass; Pandey, A., Negi, S., Binod, P., Larroche, C., Eds.; Elsevier: Amsterdam, The Netherlands, 2015; pp. 3-6. ISBN 978-0-12-800080-9.

15. Ishizaki, H.; Hasumi, K. Chapter 10-Ethanol Production from Biomass. In Research Approaches to Sustainable Biomass Systems; Tojo, S., Hirasawa, T., Eds.; Academic Press: Boston, MA, USA, 2014; pp. 243-258. ISBN 978-0-12-404609-2.

16. Mosier, N.; Wyman, C.; Dale, B.; Elander, R.; Lee, Y.Y.; Holtzapple, M.; Ladisch, M. Features of promising technologies for pretreatment of lignocellulosic biomass. Bioresour. Technol. 2005, 96, 673-686. [CrossRef]

17. Kumar, P.; Barrett, D.M.; Delwiche, M.J.; Stroeve, P. Methods for pretreatment of lignocellulosic biomass for efficient hydrolysis and biofuel production. Ind. Eng. Chem. Res. 2009, 48, 3713-3729. [CrossRef]

18. Kuna, E.; Behling, R.; Valange, S.; Chatel, G.; Colmenares, J.C. Sonocatalysis: A potential sustainable pathway for the valorization of lignocellulosic biomass and derivatives. Top. Curr. Chem. 2017, 375, 41. [CrossRef] [PubMed]

19. Roohinejad, S.; Koubaa, M.; Barba, F.J.; Greiner, R.; Orlien, V.; Lebovka, N.I. Negative pressure cavitation extraction: A novel method for extraction of food bioactive compounds from plant materials. Trends Food Sci. Technol. 2016, 52, 98-108. [CrossRef]

20. Cheng, H.-T.; Shen, X.-S. The technology of extracting tea polyphenols by cavitation. Mod. Chem. Ind. 2016, 36, 157-160.

21. Lee, I.; Han, J.-I. Simultaneous treatment (cell disruption and lipid extraction) of wet microalgae using hydrodynamic cavitation for enhancing the lipid yield. Bioresour. Technol. 2015, 186, 246-251. [CrossRef]

22. Lee, I.; Oh, Y.-K.; Han, J.-I. Design optimization of hydrodynamic cavitation for effectual lipid extraction from wet microalgae. J. Environ. Chem. Eng. 2019, 7, 102942. [CrossRef]

23. Iskalieva, A.; Yimmou, B.M.; Gogate, P.R.; Horvath, M.; Horvath, P.G.; Csoka, L. Cavitation assisted delignification of wheat straw: A review. Ultrason. Sonochem. 2012, 19, 984-993. [CrossRef]

24. Thangavelu, K.; Desikan, R.; Taran, O.P.; Uthandi, S. Delignification of corncob via combined hydrodynamic cavitation and enzymatic pretreatment: Process optimization by response surface methodology. Biotechnol. Biofuels 2018, 11, 203. [CrossRef]

25. Badve, M.P.; Gogate, P.R.; Pandit, A.B.; Csoka, L. Hydrodynamic cavitation as a novel approach for delignification of wheat straw for paper manufacturing. Ultrason. Sonochem. 2014, 21, 162-168. [CrossRef]

26. Baxi, P.B.; Pandit, A.B. Using cavitation for delignification of wood. Bioresour. Technol. 2012, 110, 697-700. [CrossRef]

27. Asaithambi, N.; Singha, P.; Dwivedi, M.; Singh, S.K. Hydrodynamic cavitation and its application in food and beverage industry: A review. J. Food Process Eng. 2019, 42, e13144. [CrossRef]

28. Mishra, K.P.; Gogate, P.R. Intensification of degradation of Rhodamine B using hydrodynamic cavitation in the presence of additives. Sep. Purif. Technol. 2010, 75, 385-391. [CrossRef]

29. Hilares, R.T.; Ramos, L.; da Silva, S.S.; Dragone, G.; Mussatto, S.I.; Santos, J.C.D. Hydrodynamic cavitation as a strategy to enhance the efficiency of lignocellulosic biomass pretreatment. Crit. Rev. Biotechnol. 2018, 38, 483-493. [CrossRef]

30. Gogate, P.R. Alternative Energy Sources for Green Chemistry; Stefanidis, A.G., Stankiewicz, A., Eds.; Royal Society of Chemistry: London, UK, 2016; pp. 126-160.

31. Gogate, P.R. Hydrodynamic cavitation for food and water processing. Food Bioprocess Technol. 2011, 4, 996-1011. [CrossRef]

32. Albanese, L.; Ciriminna, R.; Meneguzzo, F.; Pagliaro, M. Beer-brewing powered by controlled hydrodynamic cavitation: Theory and real-scale experiments. J. Clean. Prod. 2017, 142, 1457-1470. [CrossRef]

33. Capocelli, M.; Prisciandaro, M.; Lancia, A.; Musmarra, D. Comparison between hydrodynamic and acoustic cavitation in microbial cell disruption. Chem. Eng. Trans. 2014, 38, 13-18.

34. Askarian, M.; Vatani, A.; Edalat, M. Heavy oil upgrading via hydrodynamic cavitation in the presence of an appropriate hydrogen donor. J. Pet. Sci. Eng. 2017, 151, 55-61. [CrossRef]

35. Gaikwad, V.; Gaikwad, S.; Ranade, V. Effect of orifice shape on water disinfection efficacy. Pollut. Res. 2016, 35, 765-771.

36. Agrawal, N.; Maddikeri, G.L.; Pandit, A.B. Sustained release formulations of citronella oil nanoemulsion using cavitational techniques. Ultrason. Sonochem. 2017, 36, 367-374. [CrossRef] 
37. Dong, Z.; Zhao, W. Killing rate of colony count by hydrodynamic cavitation due to square multi-orifice plates. In IOP Conference Series: Earth and Environmental Science, Proceedings of the International Conference on Energy Engineering and Environmental Protection (EEEP2017), Sanya, China, 20-22 November 2017; IOP Science: Bristol, UK, 2018; Volume 121, p. 022004.

38. Terán Hilares, R.; de Almeida, G.F.; Ahmed, M.A.; Antunes, F.A.F.; da Silva, S.S.; Han, J.-I.; Santos, J.C.D. Hydrodynamic cavitation as an efficient pretreatment method for lignocellulosic biomass A parametric study. Bioresour. Technol. 2017, 235, 301-308. [CrossRef]

39. Sawant, S.S.; Anil, A.C.; Krishnamurthy, V.; Gaonkar, C.; Kolwalkar, J.; Khandeparker, L.; Desai, D.; Mahulkar, A.V.; Ranade, V.V.; Pandit, A.B. Effect of hydrodynamic cavitation on zooplankton: A tool for disinfection. Chem. Eng. J. 2008, 42, 320-328. [CrossRef]

40. Nakashima, K.; Ebi, Y.; Shibasaki-Kitakawa, N.; Soyama, H.; Yonemoto, T. Hydrodynamic cavitation reactor for efficient pretreatment of lignocellulosic biomass. Ind. Eng. Chem. Res. 2016, 55, 1866-1871. [CrossRef]

41. More, N.S.; Gogate, P.R. Intensified degumming of crude soybean oil using cavitational reactors. J. Food Eng. 2018, 218, 33-43. [CrossRef]

42. Nemchin, A. New Technological cavitation-induced effects of heat and mass transfer. Heat Transf. Res. 1999, 30, 275-288. [CrossRef]

43. Bałdyga, J.; Makowski, Ł.; Orciuch, W.; Sauter, C.; Schuchmann, H.P. Deagglomeration processes in high-shear devices. Chem. Eng. Res. Des. 2008, 86, 1369-1381. [CrossRef]

44. Bałdyga, J.; Orciuch, W.; Makowski, Ł.; Malski-Brodzicki, M.; Malik, K. Break up of nano-particle clusters in high-shear devices. Chem. Eng. Process. Process Intensif. 2007, 46, 851-861. [CrossRef]

45. Find, J.; Emerson, S.C.; Krausz, I.M.; Moser, W.R. Hydrodynamic cavitation as a tool to control macro-, micro-, and nano-properties of inorganic materials. J. Mater. Res. 2001, 16, 3503-3513. [CrossRef]

46. Moser, W.R.; Find, J.; Emerson, S.C.; Krausz, I.M. Engineered synthesis of nanostructured materials and catalysts. Adv. Chem. Eng. 2001, 27, 1-48.

47. Sunstrom IV, J.E.; Moser, W.R.; Marshik-Guerts, B. General route to nanocrystalline oxides by hydrodynamic cavitation. Chem. Mater. 1996, 8, 2061-2067. [CrossRef]

48. Moser, W.R.; Marshik, B.J.; Kingsley, J.; Lemberger, M.; Willette, R.; Chan, A.; Sunstrom IV, J.E.; Boye, A. The synthesis and characterization of solid-state materials produced by high shear-hydrodynamic cavitation. J. Mater. Res. 1995, 10, 2322-2335. [CrossRef]

49. Kuldeep; Saharan, V.K. Computational study of different venturi and orifice type hydrodynamic cavitating devices. J. Hydrodyn. 2016, 28, 293-305. [CrossRef]

50. Cerecedo, L.M.; Dopazo, C.; Gomez-Lus, R. Water disinfection by hydrodynamic cavitation in a rotor-stator device. Ultrason. Sonochem. 2018, 48, 71-78. [CrossRef] [PubMed]

51. Sun, X.; Park, J.J.; Kim, H.S.; Lee, S.H.; Seong, S.J.; Om, A.S.; Yoon, J.Y. Experimental investigation of the thermal and disinfection performances of a novel hydrodynamic cavitation reactor. Ultrason. Sonochem. 2018, 49, 13-23. [CrossRef] [PubMed]

52. Badve, M.P.; Alpar, T.; Pandit, A.B.; Gogate, P.R.; Csoka, L. Modeling the shear rate and pressure drop in a hydrodynamic cavitation reactor with experimental validation based on KI decomposition studies. Ultrason. Sonochem. 2015, 22, 272-277. [CrossRef] [PubMed]

53. Rinaldi, L.; Wu, Z.; Giovando, S.; Bracco, M.; Crudo, D.; Bosco, V.; Cravotto, G. Oxidative polymerization of waste cooking oil with air under hydrodynamic cavitation. Green Process. Synth. 2017, 6, 425-432. [CrossRef]

54. Crudo, D.; Bosco, V.; Cavaglià, G.; Grillo, G.; Mantegna, S.; Cravotto, G. Biodiesel production process intensification using a rotor-stator type generator of hydrodynamic cavitation. Ultrason. Sonochem. 2016, 33, 220-225. [CrossRef]

55. Kim, H.; Sun, X.; Koo, B.; Yoon, J.Y. Experimental investigation of sludge treatment using a rotor-stator type hydrodynamic cavitation reactor and an ultrasonic bath. Processes 2019, 7, 790. [CrossRef]

56. Maa, Y.-F.; Hsu, C. Liquid-liquid emulsification by rotor/stator homogenization. J. Controlled Release 1996, 38, 219-228. [CrossRef]

57. Burmistrov, V.A.; Lipatova, I.M.; Losev, N.V.; Rodicheva, J.A.; Koifman, O.I. Influence of the composition and high shear stresses on the structure and properties of hybrid materials based on starch and synthetic copolymer. Carbohydr. Polym. 2018, 196, 368-375. [CrossRef]

58. Petkovšek, M.; Zupanc, M.; Dular, M.; Kosjek, T.; Heath, E.; Kompare, B.; Širok, B. Rotation generator of hydrodynamic cavitation for water treatment. Sep. Purif. Technol. 2013, 118, 415-423. [CrossRef] 
59. Petkovšek, M.; Mlakar, M.; Levstek, M.; Stražar, M.; Širok, B.; Dular, M. A novel rotation generator of hydrodynamic cavitation for waste-activated sludge disintegration. Ultrason. Sonochem. 2015, 26, 408-414. [CrossRef] [PubMed]

60. Gogate, P.R. Cavitation: An auxiliary technique in wastewater treatment schemes. Adv. Environ. Res. 2002, 6, 335-358. [CrossRef]

61. Gogate, P.R.; Shirgaonkar, I.Z.; Sivakumar, M.; Senthilkumar, P.; Vichare, N.P.; Pandit, A.B. Cavitation reactors: Efficiency assessment using a model reaction. AIChE J. 2001, 47, 2526-2538. [CrossRef]

62. Wu, Z.; Franke, M.; Ondruschka, B.; Zhang, Y.; Ren, Y.; Braeutigam, P.; Wang, W. Enhanced effect of suction-cavitation on the ozonation of phenol. J. Hazard. Mater. 2011, 190, 375-380. [CrossRef]

63. Wu, Z.; Ondruschka, B.; Zhang, Y.; Bremner, D.H.; Shen, H.; Franke, M. Chemistry driven by suction. Green Chem. 2009, 11, 1026. [CrossRef]

64. Wu, Z.; Shen, H.; Ondruschka, B.; Zhang, Y.; Wang, W.; Bremner, D.H. Removal of blue-green algae using the hybrid method of hydrodynamic cavitation and ozonation. J. Hazard. Mater. 2012, 235-236, 152-158. [CrossRef]

65. Kumar, P.S.; Pandit, A.B. Modeling hydrodynamic cavitation. Chem. Eng. Technol. 1999, 22, 1017-1027. [CrossRef]

66. Li, P.; Song, Y.; Yu, S.; Park, H.-D. The effect of hydrodynamic cavitation on Microcystis aeruginosa: Physical and chemical factors. Chemosphere 2015, 136, 245-251. [CrossRef]

67. Gogate, P.R. Application of cavitational reactors for water disinfection: Current status and path forward. J. Environ. Manag. 2007, 85, 801-815. [CrossRef]

68. Sivakumar, M.; Pandit, A.B. Wastewater treatment: A novel energy efficient hydrodynamic cavitational technique. Ultrason. Sonochem. 2002, 9, 123-131. [CrossRef]

69. Zupanc, M.; Pandur, Z.; Stepišnik Perdih, T.; Stopar, D.; Petkovšek, M.; Dular, M. Effects of cavitation on different microorganisms: The current understanding of the mechanisms taking place behind the phenomenon. A review and proposals for further research. Ultrason. Sonochem. 2019, 57, 147-165. [CrossRef] [PubMed]

70. Sayyaadi, H. Assessment of tandem Venturi on enhancement of cavitational chemical reaction. J. Fluid Eng.-Trans. ASME 2009, 131, 113011-113017. [CrossRef]

71. Capocelli, M.; Musmarra, D.; Prisciandaro, M.; Lancia, A. Chemical effect of hydrodynamic cavitation: Simulation and experimental comparison. AIChE J. 2014, 60, 2566-2572. [CrossRef]

72. Zhang, X.; Fu, Y.; Li, Z.; Zhao, Z. The collapse intensity of cavities and the concentration of free hydroxyl radical released in cavitation flow. Chin. J. Chem. Eng. 2008, 16, 547-551. [CrossRef]

73. Geng, K.; Dong, Z.-Y.; Zhang, K.; Ju, W.-J.; Zhao, W.-Q.; Li, Y.-R.; Qin, Z.-Y.; Wang, L. Experimental study of Escherichia coli killed by hydrodynamic cavitation due to venturi tube. J. Environ. Sci. 2017, 37, 3385-3391.

74. Karamah, E.F.; Sunarko, I. Disinfection of bacteria Escherichia coli using hydrodynamic cavitation. Int. J. Technol. 2013, 4, 209-216. [CrossRef]

75. Maddikeri, G.L.; Gogate, P.R.; Pandit, A.B. Intensified synthesis of biodiesel using hydrodynamic cavitation reactors based on the interesterification of waste cooking oil. Fuel 2014, 137, 285-292. [CrossRef]

76. Pawar, S.K.; Mahulkar, A.V.; Pandit, A.B.; Roy, K.; Moholkar, V.S. Sonochemical effect induced by hydrodynamic cavitation: Comparison of venturi/orifice flow geometries. AIChE J. 2017, 63, 4705-4716. [CrossRef]

77. Rajoriya, S.; Bargole, S.; Saharan, V.K. Degradation of reactive blue 13 using hydrodynamic cavitation: Effect of geometrical parameters and different oxidizing additives. Ultrason. Sonochem. 2017, 37, 192-202. [CrossRef]

78. Šarc, A.; Stepišnik-Perdih, T.; Petkovšek, M.; Dular, M. The issue of cavitation number value in studies of water treatment by hydrodynamic cavitation. Ultrason. Sonochem. 2017, 34, 51-59. [CrossRef]

79. Pradhan, A.A.; Gogate, P.R. Removal of p-nitrophenol using hydrodynamic cavitation and Fenton chemistry at pilot scale operation. Chem. Eng. J. 2010, 156, 77-82. [CrossRef]

80. Suslick, K.S.; Mdleleni, M.M.; Ries, J.T. Chemistry induced by hydrodynamic cavitation. J. Am. Chem. Soc. 1997, 119, 9303-9304. [CrossRef]

81. Zhang, J.; Xu, S.; Li, W. High shear mixers: A review of typical applications and studies on power draw, flow pattern, energy dissipation and transfer properties. Chem. Eng. Process. Process Intensif. 2012, 57-58, $25-41$. [CrossRef] 
82. Bałdyga, J.; Orciuch, W.; Makowski, Ł.; Malik, K.; Özcan-Taşkin, G.; Eagles, W.; Padron, G. Dispersion of nanoparticle clusters in a rotor-stator mixer. Ind. Eng. Chem. Res. 2008, 47, 3652-3663. [CrossRef]

83. Moussa, M.; Perrier-Cornet, J.-M.; Gervais, P. Damage in Escherichia coli cells treated with a combination of high hydrostatic pressure and subzero temperature. Appl. Environ. Microbiol. 2007, 73, 6508-6518. [CrossRef]

84. Hewitt, C.J.; Boon, L.A.; McFarlane, C.M.; Nienow, A.W. The use of flow cytometry to study the impact of fluid mechanical stress on Escherichia coli W3110 during continuous cultivation in an agitated bioreactor. Biotechnol. Bioeng. 1998, 59, 612-620. [CrossRef]

85. Croughan, M.S.; Sayre, E.S.; Wang, D.I.C. Viscous reduction of turbulent damage in animal cell culture. Biotechnol. Bioeng. 1989, 33, 862-872. [CrossRef]

86. Lakhotia, S.; Papoutsakis, E.T. Agitation induced cell injury in microcarrier cultures. Protective effect of viscosity is agitation intensity dependent: Experiments and modeling. Biotechnol. Bioeng. 1992, 39, 95-107. [CrossRef]

87. Dreosti, I.E. Bioactive ingredients: Antioxidants and polyphenols in tea. Nutr. Rev. 1996, 54, S51-S58. [CrossRef]

88. Pan, X.; Niu, G.; Liu, H. Microwave-assisted extraction of tea polyphenols and tea caffeine from green tea leaves. Chem. Eng. Process. 2003, 42, 129-133. [CrossRef]

89. Chemat, F.; Zill-E-Huma; Khan, M.K. Applications of ultrasound in food technology: Processing, preservation and extraction. Ultrason. Sonochem. 2011, 18, 813-835. [CrossRef] [PubMed]

90. Vilkhu, K.; Mawson, R.; Simons, L.; Bates, D. Applications and opportunities for ultrasound assisted extraction in the food industry-A review. Innov. Food Sci. Emerg. Technol. 2008, 9, 161-169. [CrossRef]

91. Miao, S.-F.; Yu, J.-P.; Du, Z.; Guan, Y.-X.; Yao, S.-J.; Zhu, Z.-Q. Supercritical fluid extraction and micronization of ginkgo flavonoids from ginkgo biloba leaves. Ind. Eng. Chem. Res. 2010, 49, 5461-5466. [CrossRef]

92. Malovanyy, M.; Nikiforov, V.; Kharlamova, O.; Synelnikov, O. Production of renewable energy resources via complex treatment of cyanobacteria biomass. Chem. Chem. Technol. 2016, 10, 251-254. [CrossRef]

93. Dong, Y.-Y.; Li, S.-M.; Ma, M.-G.; Zhao, J.-J.; Sun, R.-C.; Wang, S.-P. Environmentally-friendly sonochemistry synthesis of hybrids from lignocelluloses and silver. Carbohydr. Polym. 2014, 102, 445-452. [CrossRef] [PubMed]

94. Terán Hilares, R.; dos Santos, J.C.; Ahmed, M.A.; Jeon, S.H.; da Silva, S.S.; Han, J.-I. Hydrodynamic cavitation-assisted alkaline pretreatment as a new approach for sugarcane bagasse biorefineries. Bioresour. Technol. 2016, 214, 609-614. [CrossRef] [PubMed]

95. Terán Hilares, R.; Kamoei, D.V.; Ahmed, M.A.; da Silva, S.S.; Han, J.-I.; Santos, J.C.D. A new approach for bioethanol production from sugarcane bagasse using hydrodynamic cavitation assisted-pretreatment and column reactors. Ultrason. Sonochem. 2018, 43, 219-226. [CrossRef] [PubMed]

96. Ancza, E.; Diószegi, M.B.; Horváth, M. Hydrodynamic cavitation device that makes straw cuts suitable for efficient biogas production. Appl. Mech. Mater. 2014, 564, 572-576. [CrossRef]

97. Zieliński, M.; Dębowski, M.; Kisielewska, M.; Nowicka, A.; Rokicka, M.; Szwarc, K. Comparison of ultrasonic and hydrothermal cavitation pretreatments of cattle manure mixed with straw wheat on fermentative biogas production. Waste Biomass Valori. 2017, 10, 747-754. [CrossRef]

98. 2018-Italian Patent n. 102016000007489. Available online: https://www.epic-srl.com (accessed on 14 December 2019).

99. Calcio Gaudino, E.; Grillo, G.; Cravotto, G.; Daniele, C.; Thomas, D.; Gerhard, S.; Liga, L.; Galina, T.; Ochoa-gómez, J.R. High-intensity ultrasound and hydrodynamic cavitation as powerful treament for biomass conversion. In Proceedings of the 4th International Congress on Catalysis for Biorefineries, Catbior 2017, Université Lyon, Lyon, France, 11-15 December 2017; Volume 2, p. 168.

(C) 2019 by the authors. Licensee MDPI, Basel, Switzerland. This article is an open access article distributed under the terms and conditions of the Creative Commons Attribution (CC BY) license (http://creativecommons.org/licenses/by/4.0/). 